Selcuk Journal of Agriculture and Food Sciences

http://sjafs.selcuk.edu.tr/sjafs/index

Research Article
SJAFS

(2019) 33 (1), 14-18

e-ISSN: $2458-8377$

DOI: $10.15316 /$ SJAFS.2019.150

\title{
Effects of Bacterial Inoculation and Molybdenum Application on Nutrient Element Content of Beans
}

\author{
Ummahan ÇETIN KARACA ${ }^{1, *}$, Emel ATMACA ${ }^{1}$ \\ ${ }^{1}$ Selçuk University, Faculty of Agriculture, Department of Soil Science and Plant Nutrition, Konya, Turkey
}

\begin{tabular}{l}
\hline ARTICLE INFO \\
\hline Article history: \\
Received date: 10.01 .2019 \\
Accepted date: 19.03 .2019 \\
\hline Edited by: \\
Kazım ÇARMAN; Selçuk University, \\
Turkey \\
Reviewed by: \\
Mustafa ÖNDER; Selcuk Universiy, \\
Turkey \\
Ayten NAMLI; Ankara University, \\
Turkey \\
\hline Keywords: \\
Akman 98 \\
Dry Beans \\
Rhizobium \\
Molybdenum \\
Nutrient Elements \\
\hline
\end{tabular}

\begin{abstract}
This study was carried out to determine the effect of different doses of molybdenum with bacterial inoculation on macro and micro- elements content of bean grains. In this study, Akman 98 dry bean variety was used as plant material, Molybdenum dosages were $\mathrm{Mo0}=$ Molybdenum free, $\mathrm{Mo1}=0.05 \mathrm{mg} / \mathrm{kg}$, Mo2 $=0.10 \mathrm{mg} / \mathrm{kg}$ and Rhizobium tropici (CIAT899), bacterium of Phaseolus plant, was used as inoculation material. The study was planned according to the randomized complete blocks in factorial design with three replicates. Following the performed field trial, nutrient elements $(\mathrm{N}, \mathrm{P}, \mathrm{K}, \mathrm{Ca}, \mathrm{Mg}, \mathrm{Fe}, \mathrm{Cu}$, $\mathrm{Mn}$, and $\mathrm{Zn}$ ) of bean grains were determined. According to the results obtained from the study, the effect of molybdenum application and inoculation on nutrient elements of bean grains was different and statistically significant. This effect on nutrients showed that the nutrients in the bean grains generally increased due to the increase in molybdenum doses. Mineral content of bean grains were determined as nitrogen $(\mathrm{N}) 3.59-4.39$, protein content 22.44-27.44, phosphorus $(\mathrm{P})$ 0.36-0.46 potassium $(\mathrm{K})$ 1.83-2.33 magnesium $(\mathrm{Mg})$ 0.17-0.20 calcium $(\mathrm{Ca})(\%)$, as $\mathrm{mg} / \mathrm{kg}(\mathrm{Fe})$ 37.59-65.25 copper $(\mathrm{Cu})$ 5.27-7.69 manganese (Mn) 14.98-16.96 zinc (Zn) 14.77-27.28. The nutrient contents of inoculated bean grains were found to be higher than the non-inoculated ones. Nutrient contents were different depending on the inoculation and dose applications, and this difference was found to be statistically significant.
\end{abstract}

\section{Introduction}

The beans enrich the soil with nutrients by removing the nutrients found in the lower layers of the soil to the soil surface through the advanced root systems. Beans meet most nitrogen needs from the soil air by utilizing the free nitrogen of the air through the bacterium Rhizobium phaseoli with a common life feature in its roots, and it enriches the soil in which they grow with nitrogen. In this way, an average of $5 \mathrm{~kg} / \mathrm{da}$ of nitrogen per year are able to fixed. The loss of nitrogen in this way is less than that of nitrogenous fertilizers, it does not lead to pollution of drinking water and does not cause the quality deficiency resulting from chemical fertilization (Akçin, 1976).

When the microorganisms, which bind the free nitrogen of the air to the soil by establishing symbiotic life with leguminous plants and generally known as Rhizobium spp. are not given to the soil, they are generally found in the soil in limited number or they are not effective. For this reason, the amount of nitrogen bound to the soil by biological means is low in the situations without inoculation (Gök and Onaç, 1995).

\footnotetext{
*Corresponding author email: ucetin@selcuk.edu.tr
}

If the seed is cultivated by inoculation with effective bacterial strains, nodosites will occur early in the development of the plant roots and the plant may complete its development without being affected by lack of nitrogen in the soil. The nitrogen supplied to the plant through nodosites enters the plant metabolism as organic compounds and the plant can easily benefit from these compounds (Haktanir and Arcak, 1997).

Bergersen (1971) reported that molybdenum plays a role in the basic mechanism of nitrogen fixation by activating nitrogenase enzyme and it is an important element for bacteria that co-live with high plants and fix nitrogen. Many investigators have shown that bacterial inoculation in legumes affects nitrogen content in vegetative growth, dry matter formation, grain yield, nodulation, vegetative growth, nodule and granule (Gök and Onaç, 1995).

Molybdenum deficiency is observed in plants grown in soil with molybdenum below $0.025 \mathrm{~kg}$ in decadence (Aydemir, 1985). Some plants have higher requirements for molybdenum. For example, in terms of nitrogen determination, Leguminous plants and Cruciferae family plants, especially cauliflower and cabbage, have higher need for molybdenum. This research was carried out to determine bacterial inoculation, 
which is important in protein rich grain yield, and to determine the effect of different molybdenum doses on nutrient content of bean grains due to increased nodulation and nitrogen detection in plants.

\section{Materials and Methods}

In this study, Akman 98 bean (Phaseolus vulgaris L.), which is the registered product of Anatolia Agricultural Research Institute, was used as bean variety and, as bacteria, Rhizobium tropici (CIAT899) was used, which was provided from the biological laboratories of Soil, Fertilizer and Water Resources Central Research Institute Directorate, Ankara. The trial was set up according to randomized block experimental designs with three replications and it was carried out in field conditions as a two-year study. In the experiment, each plot size was $2.5 \mathrm{~m} \times 2 \mathrm{~m}$, row spacing was 50 $\mathrm{cm}$, and row top was $20 \mathrm{~cm}$. This is a complete factorial treatments design, with factor A (2 levels: inoculated and non-inoculated) and factor $\mathrm{B}$ (3 levels: $\mathrm{Mo}_{0}=$ without molybdenum, $\mathrm{Mo}_{1}=0.05 \mathrm{mg} / \mathrm{kg}, \mathrm{Mo}_{2}=0.10 \mathrm{mg} / \mathrm{kg}$ ).

After these plots were made ready for planting and after the surface sterilization of the seeds was made with $0.5 \%$ sodium hypochlorite, they were sown by inoculation of Rhizobium tropici bacteria developed in YMB (Yeast mannitol broth). The study was carried out on a total of 24 plots including 3 molybdenum dozes, 2 inoculation factors and 4 replications. The amount of seed was calculated for each plot, and placed in a polyethylene bag. Seed surfaces were soaked by adding $10 \%$ sucrose solution in $1 \%$ ratio to the bean seeds in the polyethylene bags which were going to be used in the parcels to be inoculated. $1 \%$ inoculant was added to the bag, and the bags were swayed gently, allowing the inoculant to stick to the seeds. The seeds were dried in the shade and then planted immediately. So as to prevent contamination, first the control was done and the parcels with bacterial inoculation were planted. The planting was made in a plant population of $50 \mathrm{~cm}$ between rows and $20 \mathrm{~cm}$ row top. It was made in the evening to avoid the negative effects of sun rays on bacteria. In the field trial macro element base fertilizer was applied to all parcels during sowing as $4 \mathrm{~kg} \mathrm{~N} / \mathrm{da}\left(\mathrm{NH}_{4}\right)_{2} \mathrm{SO}_{4}(\% 21 \mathrm{~N}), 6 \mathrm{~kg} \mathrm{P}_{2} \mathrm{O}_{5} / \mathrm{da} \mathrm{TSP}$ $\left(\begin{array}{llll}\% & 45 & \mathrm{P}_{2} \mathrm{O}_{5}\end{array}\right), 5 \mathrm{~kg} \mathrm{~K} \mathrm{~K}_{2} \mathrm{O} / \mathrm{da} \mathrm{K}_{2} \mathrm{SO}_{4}\left(\begin{array}{lll}\% & 50 & \mathrm{~K}_{2} \mathrm{O}\end{array}\right)$ and micro element base fertilizer was given as $5 \mathrm{mg} \mathrm{kg}^{-1}$ $\mathrm{Fe}, 12 \mathrm{mg} \mathrm{kg}^{-1} \mathrm{Mn}, 2 \mathrm{mg} \mathrm{kg}^{-1} \mathrm{Zn}, 1 \mathrm{mg} \mathrm{kg}^{-1} \mathrm{Cu}$.

The analysis of the soil sample used in the test was performed according to texture: Bouyocous (1951), pH: Richards (1954), EC: U.S. Salinity Lab. Staff (1954), organic matter: Smith and Weldon (1941), $\mathrm{CaCO}_{3}$ : Hizalan and Ünal (1966), total nitrogen: Bremner (1965), phosphorus: Olsen et al., (1954), changeable cations: Knudsen et al. (1982), trace elements Soltanpour and Workman (1981). Some physical and chemical properties of the research soil are given in Table 1. After 90 days of vegetation, plants were harvested by hand. Following the harvest, nutrient element (N, P, K, Ca, Mg, Fe, Cu, Mn and Zn) analysis of plant seeds was performed using method of wet decomposition (Bayraklı 1987) with sulphuric acid (Lindsay and Norwell 1978).

Table 1

Some physical and chemical characteristics of soil used at experiment.

\begin{tabular}{|c|c|c|c|c|}
\hline Properties & Value & Properties & & Value \\
\hline $\mathrm{pH}$ & 7.67 & $\mathrm{Fe}$ & & 3.42 \\
\hline $\mathrm{EC}\left(\mathrm{dSm}^{-1}\right)$ & 0.313 & $\mathrm{Cu}$ & & 5.88 \\
\hline$\% \mathrm{CaCO}_{3}$ & 22.42 & Mn & Top & 36.18 \\
\hline$\%$ Organic Matter & 1.20 & $\mathrm{Zn}$ & $\stackrel{60}{\Xi}$ & 2.46 \\
\hline$\%$ Clay & 24.2 & B & & 3.92 \\
\hline$\%$ Silt & 32.6 & Mo & & 0.015 \\
\hline$\%$ Sand & 43.2 & $\mathrm{Ca}$ & on & 1.8 \\
\hline Class & Loam & $\mathrm{Mg}$ & 8 & 1.6 \\
\hline $\mathrm{N}\left(\mathrm{mg} \mathrm{kg}^{-1}\right)$ & 111.23 & $\mathrm{~K}$ & $\underset{0}{0}$ & 0.99 \\
\hline $\mathrm{P}\left(\mathrm{mg} \mathrm{kg}^{-1}\right)$ & 13.60 & & $\tilde{\Xi}$ & \\
\hline
\end{tabular}

\section{Statistical Analysis}

Data were analyzed as a factorial experiment in a completely randomized manner with three replications using the JMP statistical software version 5.1 (SAS Institute INc., Cary, NC, USA). Sources of variation were treatments, incubation day and their interaction. Means were compared by Student's t-test at a significance level of 0.05 .

\section{Results and Discussion}

In order to determine the effect of bacterial inoculation and molybdenum application of Akman 98 bean variety on the nutrients of the beans, nutrients were determined as (N, P, K, Ca, Mg, Fe, Cu, Mn, Zn) in the bean grains in this study. According to the results obtained from the study, the effect of molybdenum application and inoculation on nutrient elements of the bean grains was different and statistically significant (Table 2). It was found that with the increase of the molybdenum doses of this effect to the nutrients, the nutrients in the bean grains were generally increased. Mineral content in bean seeds were as following; $(\mathrm{Fe})$ $37.59-65.25(\mathrm{mg} / \mathrm{kg})$ in the form of calcium $(\mathrm{Ca})$ 0.17-0.20 (\%), magnesium (Mg) 0.17-0.20 (\%), copper (Cu) 5.27-7.69 (mg/kg) manganese $(\mathrm{Mn})$ 14.98-16.96 $(\mathrm{mg} / \mathrm{kg})$ zinc $(\mathrm{Zn})$ 14.77-27.28 (mg/kg). The nutrients in the bean grains of the plants that were inoculated 
were found to be higher than those that were not inoculated. In addition, the effect of molybdenum doses on the nutrients of the plant was also found to be statistically significant. Mo is an important micronutrient element for biological $\mathrm{N}$-fixation in soil and acts as a central metal ion for both NA (Neuraminidase) and NR (Nitrat redüktaz) enzymes in cofactors (Mendel and Hänsch 2002).

Table 2

The results of variance analysis of rhizobium inoculation and Mo application on the macro and micro nutrient element content of beans seed

\begin{tabular}{lccccccccccc}
\hline \multirow{2}{*}{ Sources } & \multirow{2}{*}{$\mathrm{DF}$} & \multicolumn{2}{c}{$\mathrm{N}$} & \multicolumn{2}{c}{$\mathrm{P}$} & \multicolumn{2}{c}{} & \multicolumn{2}{c}{$\mathrm{Ca}$} & \multicolumn{3}{c}{$\mathrm{Mg}$} \\
\cline { 2 - 12 } & & $\mathrm{MS}$ & $\mathrm{F}$ & $\mathrm{MS}$ & $\mathrm{F}$ & $\mathrm{MS}$ & $\mathrm{F}$ & $\mathrm{MS}$ & $\mathrm{F}$ & $\mathrm{MS}$ & $\mathrm{F}$ \\
\hline Inoculation & 1 & 0.279 & $18.41^{* *}$ & 0.0018 & 3.00 & 0.033 & 0.58 & 0.0002 & 0.67 & 0.0003 & 1.64 \\
Dose & 2 & 0.237 & $15.65^{* *}$ & 0.0055 & $9.07^{* *}$ & 0.146 & 2.57 & 0.0014 & $5.73^{*}$ & 0.0003 & 1.56 \\
Ino. x Dose & 2 & 0.193 & $12.77^{* *}$ & 0.004 & $6.55^{*}$ & 0.064 & 1.13 & 0.0002 & 0.96 & 0.0005 & 2.27 \\
Error & 12 & 0.015 & --- & 0.0006 & --- & 0.057 & --- & 0.0028 & --- & 0.0002 & --- \\
\hline Total & 17 & --- & --- & & ----- & --- & --- & --- & --- & --- & --- \\
\hline
\end{tabular}

Table 2 (continuation)

\begin{tabular}{|c|c|c|c|c|c|c|c|c|c|}
\hline \multirow{2}{*}{ Sources } & \multirow{2}{*}{ DF } & \multicolumn{2}{|c|}{$\mathrm{Fe}$} & \multicolumn{2}{|c|}{$\mathrm{Cu}$} & \multicolumn{2}{|c|}{ Mn } & \multicolumn{2}{|c|}{$\mathrm{Zn}$} \\
\hline & & MS & $\mathrm{F}$ & MS & $\mathrm{F}$ & MS & $\mathrm{F}$ & MS & $\mathrm{F}$ \\
\hline Inoculation & 1 & 547.25 & $18.68 * *$ & 3.467 & $15.49 * *$ & 1.191 & 1.29 & 64.592 & $29.94 * *$ \\
\hline Dose & 2 & 242.69 & $8.28 * *$ & 2.814 & $12.57 * *$ & 2.254 & 2.45 & 80.91 & $37.50 * *$ \\
\hline Ino. $\mathrm{x}$ Dose & 2 & 140.34 & $4.79 *$ & 1.919 & $8.57 * *$ & 0.588 & 0.64 & 24.96 & $11.57 * *$ \\
\hline Error & 12 & 29.30 & --- & 0.224 & --- & 0.922 & --- & 2.16 & --- \\
\hline Total & 17 & --- & --- & --- & --- & --- & --- & --- & --- \\
\hline
\end{tabular}

The effect of the application of inoculation and molybdenum on the nitrogen content of the bean stem was found to be statistically significant. The nitrogen content of bean ranges from 3.59 to $4.39 \%$. Inoculation and molybdenum application increased the nitrogen content of the plant. The phosphorus contents $(0.36 \%)$ of the plants which were not inoculated were lower than the inoculated plants $(0.46 \%)$. The effect of the inoculation on the grain potassium content was differ- ent from the non-inoculated conditions, and this difference was statistically significant $(\mathrm{p}<0.05)$. The K content of non-inoculated plants was determined to be $1.83 \%$, and the potassium content of the grafted plants was found to be higher $(2.33 \%)$. By inoculation, the magnesium and calcium levels increased slightly and this increase was found to be statistically significant. The calcium and magnesium content of the bean ranges from 0.17 to $0.20 \%$.

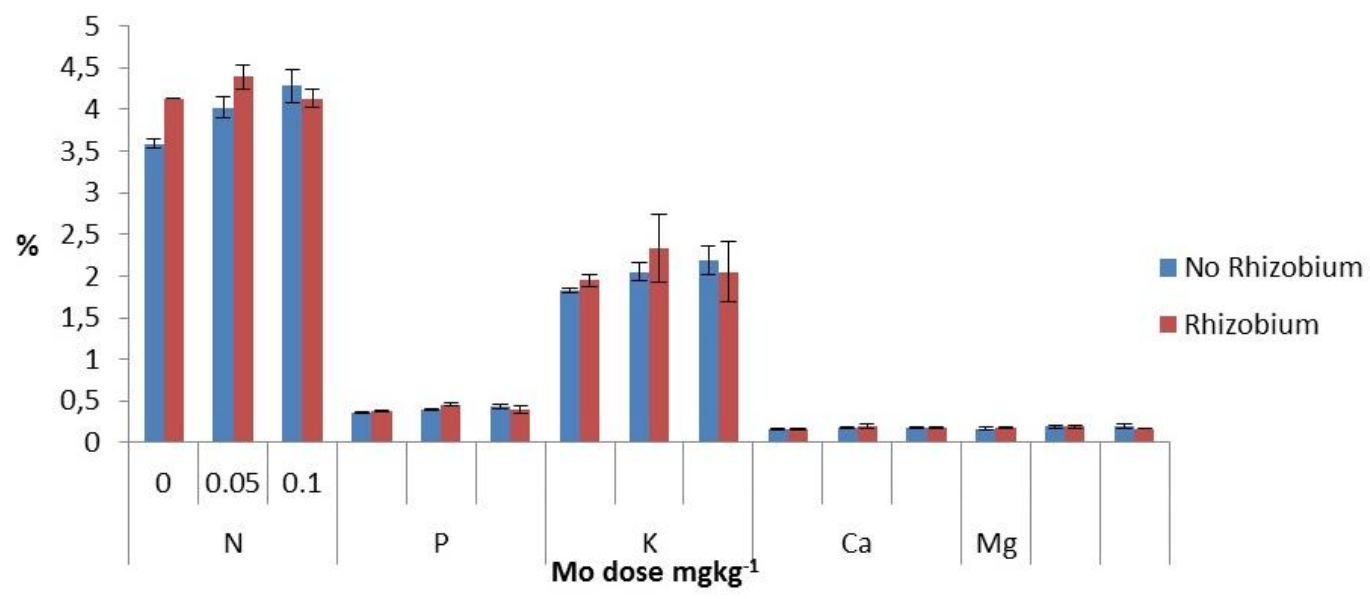

Figure 1

Effect of Rhizobium Inoculation and Mo Application on the Macro Nutrient Element Content of Beans Seed 
According to the results obtained from the research, the effect of molybdenum application and micronutrient on micronutrient elements in bean was different and statistically significant. It was found that micronutrients generally increase in micronutrients in the bean by enhancing the molybdenum doses of this effect. The content of $\mathrm{Fe}$ in beans ranged from 37.59 to 65.25 $\mathrm{mg} / \mathrm{kg}$, and the application of grafting and molybdenum increased the content of iron in the grain. The copper content $(7.69 \mathrm{mg} / \mathrm{kg})$ of the bean grains of the grafted plants was found to be higher than the grains content of uninoculated plants $(5.27 \mathrm{mg} / \mathrm{kg})$. In addition, the effect of molybdenum doses on the copper content of the plant was also found to be statistically significant. Manganese content of bean was determined between $14.98-16.96 \mathrm{mg} / \mathrm{kg}$, and the manganese contents of plants vaccinated were higher. The zinc content of the plant increased by grafting and molybdenum application and this increase was found statistically significant. The amount of zinc after non-inoculated plants was determined to be $14.77 \mathrm{mg} / \mathrm{kg}$, which increased to $27.28 \mathrm{mg} / \mathrm{kg}$ by inoculation.

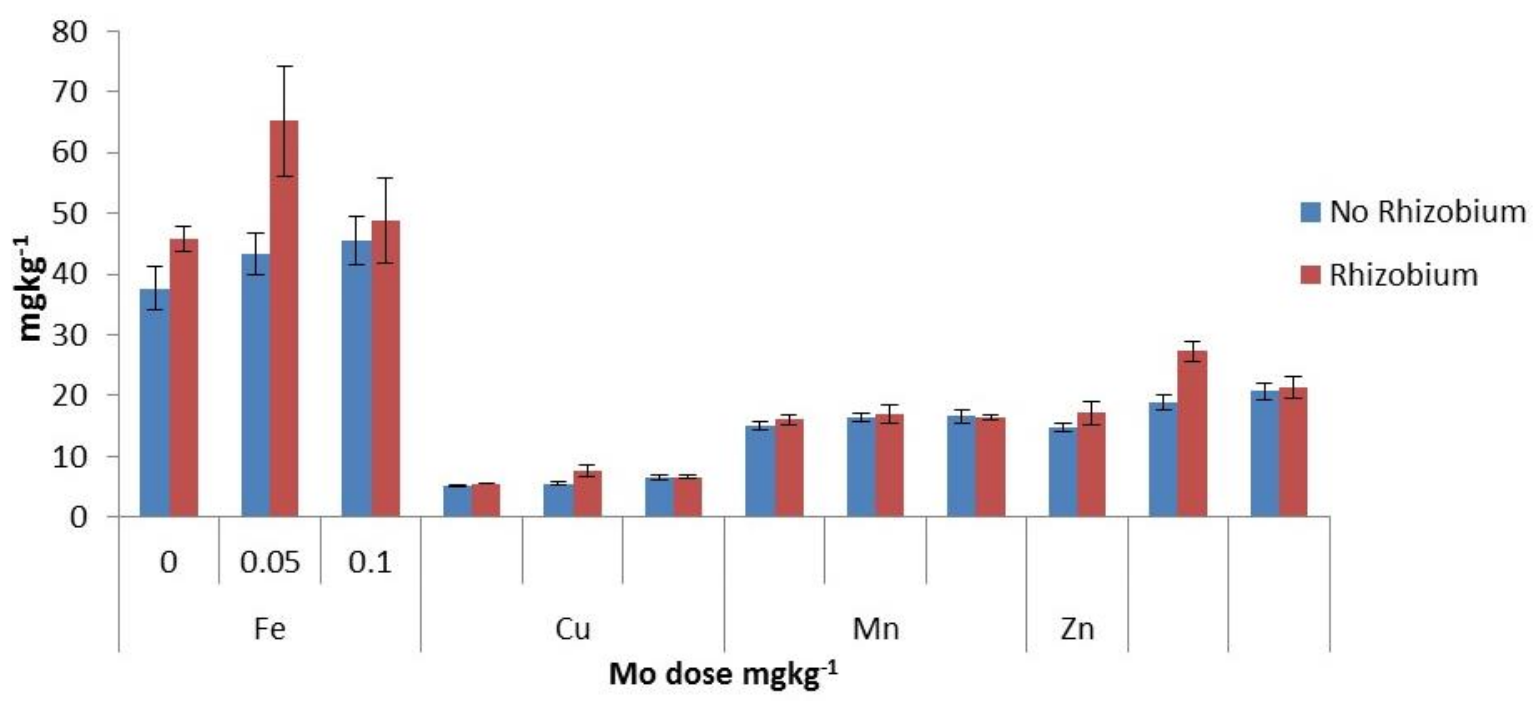

Figure 2

Effect of Rhizobium Inoculation and Mo Application on the Micro Nutrient Element Content of Beans Seed

Molybdenum is found in the structure of nitrogenase and every bacterium that binds to nitrogen needs molybdenum during fixation. Molybdenum nitrogenase is a necessary component of two important enzymes such as nitrate reductase. It was determined that nodules did not detect nitrogen even though they were formed in plants grown in soil with molybdenum deficiency. Manganese deficiency inhibits chlorophyll formation of the plant (Kızıloğlu 1995). On the other hand, Şehirali et al. (1981), Aydemir (1985), Akçin 1976, Bozoğlu et al. (1997), Gür (2002), Mut and Gülümser (2003), Nadeem et al. (2004), Önder et al. (2003), Kacar et al. (2004), Gök et al. 2003, Doğan et al., (2007), Küçük and Kıvanç (2008) have obtained similar results in their studies on this subject.

\section{Conclusion}

As a result, the common nitrogen of the leguminous Rhizobium bacterium is presented to the free nitrogen plant in the air. In this way, nitrogen binding is an important resource for agriculture. At the same time, environmental pollution from chemical fertilizers will be reduced. However, many factors such as temperature, soil moisture, salinity, soil reaction, nutrients in the soil and strains affect the nitrogen amount bound in this way, in other words, the successful Rhizobium legume plant symbiosis. Depending on these factors, the amount of nitrogen that is fixed is significantly affected. According to the obtained data, seed inoculation and micro fertilization increased the amount of the crop and the nutrient content of the grains. For this reason, it is necessary to apply molybdenum with inoculation and to apply $0.05 \mathrm{mg} \mathrm{kg}^{-1}$ Mo as the optimum dose to increase the content of nutrients in the bean grains.

\section{References}

Akçin (1976). A study on the effects of irrigation and nitrogen fertilization on grain yield, the amount of grain protein and the number of nodules in roots grown in the ecological conditions of Erzurum. Associate Professor Thesis, Atatürk University Faculty of Agriculture.

Aydemir O (1985). Plant Nutrition. Atatürk University. Agriculture Faculty Publication Tetxbook. Erzurum.

Bayraklı F (1987). Soil and Plant Analysis (Translation and Compilation) 19 Mayis University Faculty of Agriculture Pub. No:17 Samsun.

Bergersen FJ (1971). Biochemistry of symbiotic nitrogen fixatio $\mathrm{n}$ in legumes. Ann. Rev. Plant Physiol. 22:121-140. 
Bozoğlu H, Pekşen E, Gülümser A (1997). Effect of different nitrogenous fertilizers and different doses of bacterial cultivation on dry matter yield and certain properties. II. Field Crops Congress of Turkey. 22-25 September 1997. p: 183-187, Samsun.

Bouyoucos CA (1951) Hidrometer Method Improved for Making Particle Size. Analysis of Soil Agron J. 54 (5). $464-465$.

Bremner JM (1965) Methods of Soil Analysis Part 2. Chemical and Microbiological Properties. - Ed. A.C.A. Black Amer. Soc. of Agron Inc. Pub. Agron. Series No: 9 Madison USA.

Doğan K, Gök M, Çoşkan A, Güvercin E (2007). Effect of Iron Application by Bacterial Inoculation on Nodulation and Nitrogen Fixation in the 1st Groundweed Plant. Süleyman Demirel University Agricultural Faculty Magazine 2(1):35-46.

Gök M, Coşkan A, Doğan K, Arıŏlu H (2003). Influence of Iron and Molybdenum Application on Bacterial Inoculation and Nodulation and Biomass Formation in Peanut Plant, Progress Report, Project number: ZF2002BAP75.

Gök M, Onaç I (1995). Effect of in Different Nodulation, $\mathrm{N}_{2}$ Fixation and Fate Soybean Cultivars of Different Bradyrhizobium japonicum Isolates. Turkey Soil Science Society. I. Akalan Soil and Environment Symposium Volume: 2. C. 247-255. Ankara.

Gür S (2002). Some of the cultural and biochemical characteristics of isolates Rhizobium spp. isolated from lentil and bean nodules. S.D.Ü. Graduate School of Natural and Applied Sciences 6; 2, 2533.

Haktanır K, Arcak S (1997). Soil Biology, Ankara University Publication No: 1486, Ankara.

Hizalan E, Ünal H (1966). Soil chemical analysis. University of Ankara Agriculture Faculty Publics. 273. Ankara.

Kaçar O, Çakmak F, Çöplü N, Azkan N (2004). Determination of the effect of bacterial inoculation and different nitrogen doses on yield and yield components in some dry bean cultivars under Bursa conditions. Uludağ University Faculty of Agriculture. 18(1):207-218, Bursa.

Kızıloğlu (1995). Soil Microbiology and Biochemistry. Atatürk University Faculty of Agriculture Publication No: 180, Erzurum.

Knudsen DG, Peterson A, Pratt PF (1982). Lithium sodium and potassium. - In: Page AL. editor. Methods Soil Analysis. Part 2. Agronomy Monograph 9.Madison. WI. U.S.A. ASA and SSSA. p. 247-262.
Küçük Ç, Kıvanç M (2008). The effect of Rhizobium $s p$. inoculation on seed quality of bean in Turkey. Pakistan Journal of Biological Sciences 11(14): 1856-1859.

Lindsay WL, Norvell WA (1978). Development of DTPA soil test for zinc, iron, manganese and copper. Soil Sci. Soc. Am. J. 42: 421-428.

Mendel RR, Hänsch R (2002). Molybdo enzymes and molybdenum cofactor in plants. J. Exp. Bot., 53, 1689-1698. doi:10.1093/jxb/erf038.

Mut Z, Gülümser A (2003). Effects of Application of Zinc and Molybdenum with Bacterial Inoculation on Some Quality Properties of Damla-89 Chickpeas. Ondokuz May University Faculty of Agriculture Journal, 20(2):1-10, Samsun.

Nadeem MA, Ahmad R, Ahmad MS (2004). Effect of seed inoculation and different fertilizer levels on the growth and yield of mungbean (Vigna radiata L.). Journal of Agronomy 3 (1): 40-42.

Olsen SR, Cole CW, Watanabe SS, Dean LA (1954). Estimation of available phosphorus in soil by extraction by sodium bicarbonate. - USDA Agric. Circ. 939.19p

Önder M, Gezgin S, Babaoğlu M, Konuk M, Yiğit F, Ceyhan E, Yorgancilar M (2003). Symbiotic Nitrogen Fixation of dry bean and Chickpea: an Evaluation of Present Situation, Isolation of Effective Rhizobial Isolates and Inoculation With Bacteria in Konya Region, Project number: TOGTAGTARP/2041.

Richards LA (1954). Diagnosis and Improvement of Saline and Alkali Soils. - Dept. Of Agriculture. No: 60. Washington. D.C.

Smith HW, Weldon MD (1941). A Comparasion of Some Methods For The Determination of Soil Organic Matter. - Soils Sci. Soc. Amer. Proc. 5: 177-182.

Soltanpour PN, Workman SM, (1981). Use of Inductively-Coupled Plasma Spectroscopy for the Simultaneous Determination of Macro and Micro Nutrients in $\mathrm{NH}_{4} \mathrm{HCO}_{3}$-DTPA Extracts of Soils. Developments in Atomic Plasma Analysis. In: Barnes R.M. (ed). USA. 673-680.

Şehirali S, Gürgün V, Gençtan T, Çiftçi CY (1981). Effect of bacterial inoculation and different nitrogen doses on yield and protein content in beans. Soil Water Research Report, 15.

US Salinity Lab Staff (1954). Diagnosis and improvement of saline and alkali soils. - U.S. Goverment Handbook No: 60. Printing Office. Washington. 